\title{
Management Quality Enhancement Based on National Accreditation Standard of Islamic Studies Program
}

\author{
Ahmad Zainuri* \\ Education Management Department \\ Universitas Islam Negeri Raden Fatah \\ Palembang, Indonesia \\ *ahmadzainuri_uin@radenfatah.ac.id
}

\author{
Duski Ibrahim \\ Usul Fiq'h Departement, Syaria Faculty \\ Universitas Islam Negeri Raden Fatah \\ Palembang, Indonesia \\ duski_uin@radenfatah.ac.id
}

\author{
Fahmi Bafadlal \\ Pascasarjana \\ Universitas Islam Sulthan Thaha Saifuddin \\ Jambi, Indonesia \\ fahmibafadhal@gmail.com
}

\begin{abstract}
Improving the quality of education by accreditation-based is a necessity. The quality of education in Indonesia is measured by the BAN-PT which already has a standardized reference standard with a good level of quality. This article aims to describe the quality management and accreditation of Islamic Studies Study Program UIN Raden Fatah to face the 4.0 industrial revolution era. The application of management in Islamic Studies study programs essentially leads to quality improvement and accreditation, so will be able to deliver graduates to have a set of knowledge, life skills, character and ability to master and be accepted in an increasingly competitive workplace or able to create creative and productive jobs. Entering the era of the industrial revolution 4.0, Islamic Studies Study Program UIN Raden Fatah will apply an Internet or ICT-based learning approach to improve the quality of learning and improve the professionalism of teacher (teachers' development), and improve the effectiveness and efficiency of management, governance and administration. The application of learning based on the Internet in Islamic Studies study programs in order to realize excellent study programs and UIN Raden Fatah becomes international standard universities, with nationalism and Islamic characteristics.
\end{abstract}

Keywords: Islamic studies program, management quality, National Accreditation Standard

\section{INTRODUCTION}

Enlightening the excellence of education by accreditationbased is a requirement. The quality of education in Indonesia is measured by the BAN-PT which already has a standardized reference standard with a good level of quality. This paper is motivated by new challenges faced by the world of education in Indonesia today, seeking the emergence of the 4.0 industrial revolution era that is very concerned with the quality of human resources (HR). Entering the era of industrial revolution 4.0, Islamic Studies Study Program UIN Raden Fatah is undoubtedly required to implement an internet-based learning approach to improve the quality of learning and improve the professionalism of teachers, as well as improve the effectiveness and efficiency of management, governance and administration education, so as to produce high quality graduates. The application of Internet-based learning in Islamic Studies study programs in order to support the vision of Islamic Studies study programs to become excellent study programs and support the vision of UIN Raden Fatah; "Being an International Standard University, with Nationalism and Islamic Character."

In this context, the Islamic Studies study program of UIN Raden Fatah Palembang, must be oriented to the outputs relating to religious, social, political and cultural issues which are always directly dealing with the community. Therefore, the whole process of teaching and learning in the Islamic Studies study program in intellectually and morally must be independent and apart from all political interests and power also place academic freedom as a moral-intellectual principle so as not to become an ivory tower. Especially when looking at a broader level, the task carried out by UIN Raden Fatah Palembang is "the realization of professional, credible and accountable also capable governance to increase the capacity, quality and reputation of the academics of UIN Raden Fatah in the academic and non-academic fields". In line with that, the mission of UIN Raden Fatah is: 1). Building good governance in all work units and levels of the organization of UIN Raden Fatah; 2). To Building human resources educators and education that are competent, professional, with integrity and able to work together; 3). Developing patterns of higher education services that are effective, efficient, modern, 
can be said that this research is descriptive qualitative. It means, researchers analyze and describe research in an objective and detailed manner to get accurate results.

Theoretically, descriptive research is limited to the effort to reveal a problem and the situation as it is, so that it is only a disclosure of facts by analyzing data [4]. Descriptive research is that researchers try to describe research activities carried out on certain objects clearly and systematically, also carry out exploration, illustrate with the aim of being able to explain and predict the symptoms that apply on the basis of data obtained in the field [5]. In this descriptive research the researcher tries to record, analyze and interpret existing conditions. It means, collecting information about existing conditions with variables that are indicative of this study.

There are two types of data sources, that are primary and secondary data sources. The primary data source is data obtained directly from informants in the field according to the problems discussed in this study, starting from the rector, head of study programs of Islamic Studies and other stakeholders who are captured through unstructured interview techniques and snowball techniques. While secondary data source, is data obtained from another research results, scientific journals, books and others [5].

The technique of checking the validity of the data uses triangulation techniques. This technique is used to test the validity of data by comparing between different sources. In this study, triangulation was used by examining the degree of validity of finding data by comparing between the methods used, between data sources and between contexts when data was obtained. Triangulation is important, because from the use of this technique as well as one technique to find out the validity of qualitative research and even with this triangulation can increase the reliability of this research; the extent to which findings can be replicated [6].

The assumption is that qualitative research does not consist of a single reality that can be re-studied by producing the same conclusions, but a complex reality that is very complex (multitasking) and constantly changing. This qualitative research does not explicitly require reliability. But implicitly it is more appropriate to refer to the term reliability as dependability or consistency with what has been determined and implemented in this study [7].

In this study, data analysis took place from the time of data collection until the data was written in a qualitative descriptive manner. Data that has been collected is examined to see the accuracy, completeness and relevance of the research problem formulation. Furthermore, the data is coded based on each relationship between data and between data related to the formulation of research problems and even in relation to the overall research data. After the data is considered complete, then it is consulted again with the data source (tranquilization), to check the validity of the data.

Based on the research framework of this study, the characteristics of the data findings and the formulation of the problem of this research, are then determined by the classification and categorization of data and entering data in 
The planning process in Islamic Studies study program Postgraduate UIN Raden Fatah will always be based on the three pillars of higher education, namely education-teaching, research and community service. Planning in the field of education-teaching, for example, relates to the academic vision of the Study Program of Islamic Studies at the Postgraduate School of Raden Fatah. Planning is done by involving all components, so that the target of improving academic quality can be achieved well. Planning in order to improve academic quality, including; planning to improve the quality of teaching staff (lecturers), quality of graduates, management of study programs, financial planning, planning for improvement of academic support facilities, such as libraries, laboratories, and various other academic facilities.

Furthermore, planning in the research dimension describes the activities of Islamic Studies study program in the field of research. Planning in this field of research includes improving the quality of research results, quantity, and the usefulness of research results, increasing research competitiveness, improving the quality of researchers and networking and so on. Then, planning in the field of community service is a series of activities for Islamic Studies UIN Raden Fatah in the field of community service. Planning on this aspect leads to the commitment of Islamic Studies UIN Raden Fatah's study program as an agent of social change.

The description above indicates that the planning of Islamic Studies UIN Raden Fatah's study program is holistic and integral. Holistic planning is an overall plan and integral planning is intended that planning is integrated in the scope of the three pillars of University. The main tasks are organizing and staff, including planning, recruitment, selection, training and so on. Then in terms of mobilizing in Islamic Studies study program UIN Raden Fatah the task is to utilize and mobilize all human resources to work according to the assigned with maximum enthusiasm and ability. And the last is supervision. The supervision of Islamic Studies UIN Raden Fatah study program was conducted on all three pillars planning. Supervision is carried out to ensure that the planning is done correctly according to the intended purpose. Supervision is also useful to find out the obstacles faced by Islamic Studies Study Program UIN Raden Fatah in carrying out programs and activities that have been outlined in the plan.

The above description leads us to the understanding that the implementation of management in Islamic Studies study program ultimately led to the improvement of the quality and accreditation of the Islamic Studies study program itself. Quality and accredited Islamic Studies Study Program UIN Raden Fatah must be able to deliver its graduates to have a set of knowledge, life skills, character and ability to master and be accepted in an increasingly competitive world of work or able to create jobs creatively and productively. In this context, the quality of Islamic Studies study program is largely determined by quality management which includes planning, implementation and quality control as an effort to carry out continuous improvements in order to improve the ability of the organization to carry out its trident that meets quality standards. This quality management is practically a central part of the 
Internal Higher Education Quality Assurance System (SPMI) conducted by the Quality Assurance Agency (LPM). Achieving quality assurance objectives is done through SPMI to then obtain accreditation through the External Quality Assurance System (SPME) by the BAN-PT [9].

In connection with the quality assurance of education in Islamic Studies study program UIN Raden Fatah there are actually many ways that can be done, including; through Total Quality Management (TQM) and accreditation of BAN-PT. TQM is not a set of rules and regulations that are rigid, but are processes and procedures to improve the performance of an Islamic Studies study program at UIN Raden Fatah. Education quality management basically aims to look for changes in the focus of higher education, from short-term feasibility towards long-term quality improvement, and its impact on changing cultural values in higher education as shown in figure 1 [10].

Judging from the aspect of the philosophical foundation of TQM, it is a tool to improve the quality of Islamic Studies study programs that are oriented to needs and customer satisfaction. The application of TQM is very much needed by educational institutions, especially Islamic Studies study program on the consideration of good education services for customer satisfaction [11].

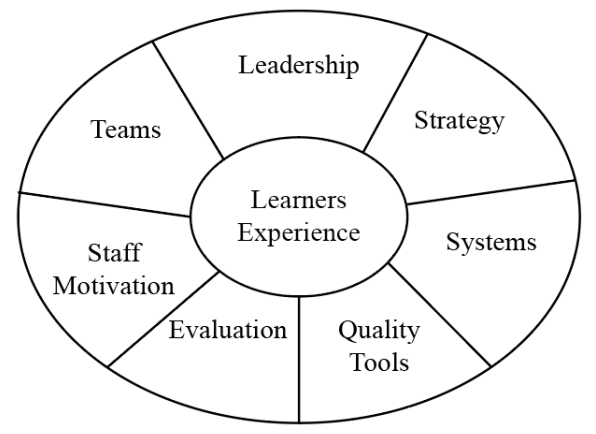

Fig. 1. Quality circle.

Although the application of TQM in Islamic Studies study program UIN Raden Fatah is very important as a manifestation of educational services for customer satisfaction. But based on findings in the field there are many factors that influence it, so that education services are not optimal. The factors that influence it are; 1). The low awareness of human resources to provide maximum service to users; 2). There is still overlapping job description, so that standard operational procedure has not been harmonious; 3 ). The low level of punishment, caused the services provided is not maximal and more preoccupied with other side jobs; and 4). The low competence of employees, for example, academic administrative staff to do the tasks assigned to them.

Regarding the above, there are several strategies that can be applied. There is at least a "Quality Management System Triangle" which is divided into three levels. At the first level, is about the form of planning and policy. At the planning stage can be seen what needs to be improved and what the customer needs. Meanwhile at the second level, is about the form of management and procedures. Then at the third level is about improving the quality. At this third level, efforts are needed to improve quality, namely following procedures, adaptations, and adjustments to field conditions.

Some of the activities that universities can carry out to realize the above strategy, for example, by increasing the determination of the dissemination of concepts and principles of Integrated Quality Management (MMT), conducting organizational leadership training and so on. However, dismantle or deconstruct the mindsets thinking of all elements of the college is also important. There was an awareness that higher education is not an institution that must be served. But on the contrary, with the principle of three pillars UIN Raden Fatah must serve the consumers. This is where the Islamic Studies study program UIN Raden Fatah had to "go down " from his "ivory tower". This is in an effort to improve the education quality standards concerned, both on a short, medium and long term scale.

In other contexts, TQM manifests in the interaction between instructors and students in the class, or in adjusting to accreditation or assessment standards. This structured system can create a learning organization. It is time for Islamic Studies study program UIN Raden Fatah to apply the principles of TQM. Difficulties in applying TQM to various higher education institutions, including Islamic Studies study programs UIN Raden Fatah, are caused by staff that unable to understand the key elements of TQM such as statistical process control, student involvement, teamwork and so on that can be used in lectures in class [12].

In the Islamic Studies study program UIN Raden Fatah, the philosophy of TQM will also help to improve morale, reduce costs, improve organizational performance and respond to the needs of its customers. For this reason, organizational effectiveness, employee participation in problem solving and decision making are needed, effective communication from senior staff and subordinates, extensive education and training, good design in recognizing and rewarding employees, qualityoriented vision, benchmarking as a continuous tool to create students who are caring, knowledgeable and able to serve the community, and support from the leader.

It must be realized that TQM is a process and at the same time as a basic philosophy that will succeed if applied simultaneously at all levels in the organization. The application of TQM does not require new equipment or management systems. What is needed is a shared commitment to change the work culture that is oriented to quality and overall improvement and continuous nature. Besides through TQM, efforts to improve the quality of Islamic Studies study program at UIN Raden Fatah can also be through the accreditation system carried out by the government, both through existing regulations and accreditation carried out by BAN-PT.

The accreditation system through BAN-PT is generally in the form of momentary observations oriented to measuring resources and content. When observing the process is done, so it is more aimed at measuring the results of the process and not much is observed about the process itself [13]. Here the accreditation system is more focused on institutions forming 
The emergence of the Master Program of Islamic Studies at UIN Raden Fatah Palembang Program was allegedly due to the increasing interest in understanding Islam as a "living religious tradition", which is historical, rather than "a collection of doctrinal arrangements" found in the Qur'an and Hadith. This phenomenon has become a global trend not only in Indonesia, but also in the universities of developed countries in the world.

In accordance with the Decree of the Rector of UIN Raden Fatah in 2017 there were eight concentrations which were officially opened in the Islamic Studies study program at the Postgraduate Program of UIN Raden Fatah Palembang, including; Concentration of Islam and Economics (IE), Islam and Pedagogics (IP), Islam and Gender (IG), Islam and Public Policy (IKP), Islam and Technology (IT), Islam and Mass Communication (IKM), Islam and Family Studies (IKK) and Malay Islamic Civilization (PIM) [14]. In this situation was intended to answer scientific, technological and artistic challenges, as well as to meet the community's needs for graduates of a study program. Therefore, the opening of a study program must really consider academic and practical significance [15].

Therefore, in line with the vision of the Islamic Studies study program to be an excellent study program, of course, in the era of industrial revolution 4.0 the challenges faced are not easy. In this era, there has been a paradigmatic shift that puts forward the penetration of globalization capable of removing boundaries of relations between countries. Developed countries are no longer measured by the amount of natural resources they have, but from how much innovation they can produce that can drive the country's economic growth. Here, the world of education, especially the study program of Islamic Studies, UIN Raden Fatah, cannot isolate itself by focusing on short goals and orientation, but must enter global competition with the demands of quality and a more open world qualification.

In this context, Islamic Studies Study program UIN Raden Fatah is required to be able to improve its quality. One of the efforts to improve the quality of Islamic Studies Study program at UIN Raden Fatah is through accreditation. Accreditation is an acknowledgment of a college or study program that shows that the college or study program in implementing the education program and the quality of the graduates it produces has met the standards set by the BAN-PT [16]. BAN-PT has the authority to carry out accreditation for all higher education institutions, both for State Universities (PTN), Private Universities (PTS), Religion Colleges (PTA) and Official Universities (PTK) and other distance education programs [17].

In accordance with Government Regulation Number 60 of 1999 and Decree of the Minister of National Education Number 118 / U / 2003, BAN-PT has a main function to assist the Minister of National Education in carrying out one of its obligations, namely the university quality assessment. In terms of the establishment of Higher Education accreditation by BAN-PT, it is conducted by assessing the process and performance as well as the linkages between the objectives, inputs, processes and outputs of a tertiary institution or study program, which is the responsibility of the respective college or study program. Accreditation provides an overview of the level 
of performance that is used as a guidance, development and improvement tool for Higher Education, both in terms of quality, effectiveness, efficiency, productivity and innovation. Thus it can be said that accreditation is one form of assessment (evaluation) of quality and feasibility of higher education institutions or study programs conducted by independent organizations or agencies outside of universities. Other forms of external quality assessment are assessments relating to accountability, licensing by certain entities.

Unlike other forms of quality assessment, BAN-PT accreditation is carried out by peer experts and those who understand the nature of the management of higher education as a team or group of assessors. Decisions about quality are based on an assessment from the various evidences related to the standards set and based on reason and consideration of the peer experts. The necessary evidence, including written reports prepared by tertiary institutions and study programs that will be accredited, are verified and validated through visits of peer experts to the college's place of residence [9]

In other words, the accreditation of Islamic Studies Study Program UIN Raden Fatah is a process of recognition that a study program has a quality assurance system that is in accordance with agreed standards and fulfillment of public and stakeholder accountability, and external quality assurance. In addition, accreditation of study programs is a comprehensive evaluation and evaluation process of its commitment to the quality and capacity of implementing the three pillars program of Higher Education, in order to determine the feasibility of study programs to organize their academic programs [17].

As a process and results, there are at least three accreditations for BAN-PT to be achieved; first, providing assurance that accredited tertiary institutions have met the quality standards set by BAN-PT, so as to provide protection for the community from the implementation of tertiary institutions that do not meet the standards. Second, encouraging universities to continuously improve and maintain high quality. Third, the results of accreditation can be used as material for consideration in transfer of credit, proposals for assistance and allocation of funds, and obtaining recognition from the concerned agency [9].

Various important regulations issued by the government related to efforts to improve the quality of Islamic Studies study program at UIN Raden Fatah appear to influence the performance in Islamic Studies study programs to show the Excellency of their education. At least since 1990 the Directorate General of Higher Education has had several programs to improve the global competitiveness of universities such as the University Research for Graduate Education (URGE) program, Development of Undergraduate Education (DUE), Quality for Undergraduate Education (QUE), SemiQUE, Technology and Professional Skills Development Projects (TPSDP) and so on. All the programs above show the sincerity of the government to improve service quality and competitiveness of universities, including the study program which will ultimately have an impact on increasing national development.
The latest regulation namely Law Number 12 of 2012 concerning Higher Education confirms that graduates competencies are determined by referring to the KKNI. This means that the Islamic Studies Study Program curriculum at UIN Raden Fatah is required to be designed as a continuation of the development of undergraduate level curricula where the master level curriculum is required to achieve level 8 of the qualification levels set by the KKNI. This regulation was implemented to ensure the competence and quality of master alumni in higher education institutions will able to achieve standard and measurable academic qualifications, abilities and attitudes [18].

Improving the quality of the service system, human resources and facilities and infrastructure is the main priority of the Islamic Studies Study program at UIN Raden Fatah towards an excellent study program. Demographic capital and regional development potential of South Sumatra and the surrounding area are very possible to be mobilized and directed through the role of Islamic Studies study program UIN Raden Fatah through the approach of interdisciplinary scientific human resource development rooted in universal human civilization.

Being very important for Islamic Studies study programs, UIN Raden Fatah to prepares and improves the quality of performance of professionals, policy makers and educators who are qualified masters and doctors as demands of human civilization. In the meantime, the modernity paradigm of HR which will be realized must remain rooted in the universality values of Islamic civilization as the core development of all characters from various scientific disciplines widely. Here is an important position as well as the Excellency of the scientific paradigm that will be developed by UIN Raden Fatah, especially Islamic Studies study programs, so that they can produce new innovations in the fields of science, technology, art and humanity [15].

Equally important, entering the industrial revolution era 4.0, Islamic Studies Study Program UIN Raden Fatah undoubtedly applies an internet-based learning approach as a method of delivery, interaction and facilitation and is supported by various other forms of learning services. ICT-based learning will be useful in providing flexibility in choosing the time and place to access teaching materials as well as independent learning, providing opportunities for learners to independently control the success of learning and cost efficiency, providing cost efficiency for administration, providing efficient facilities and physical facilities to learning and cost efficiency for learners are the costs of transportation and accommodation, facilitating and expanding access to education, increasing education equality (equity in education), improving the quality of learning (the delivery of quality learning and teaching) and increasing the professionalism teachers, also improve the effectiveness and efficiency of management, governance and educational administration.

The application of ICT-based learning in Islamic Studies study program UIN Raden Fatah must be supported by information technology devices, learning planning, good administration and management, adequate budget, the role of 
facilitators, lecturers, administrative staff, how to adopt new technologies and facilities, costs and activity schedules. The application of ICT-based learning is important so that Islamic Studies Study Program UIN Raden Fatah is not left behind with other study programs at other University.

When referring to the vision of UIN Raden Fatah to "Become an International Standard University, with Nationalism and Islamic Characteristics." This vision contains three core values or core values that form the basis of every step of development, such as "internationalization", "Indonesian" and "Islam". In the vision of "internationalization" requires all academics of UIN Raden Fatah to be able to build an international network, develop international programs, have the capacity to serve international students and make international reputation, which penetrates national boundaries [19]. Even according to international standards, Quacquarelli Symonds (QS), a research institution engaged in higher education in its release in 2010 stated that there are several core criteria that must be met by universities, including the quality of research, graduate work, teaching quality and infrastructure.

\section{CONCLUSION}

Based on the description above, it can be concluded that the application of management in Islamic Studies study program UIN Raden Fatah ultimately led to an increase in quality and accreditation. Quality and accredited Islamic Studies Study Program UIN Raden Fatah must be able to deliver its graduates to have a set of knowledge, life skills, character and ability to master and be accepted in an increasingly competitive working world or able to create jobs creatively and productively.

The quality of Islamic Studies Study Program UIN Raden Fatah is very much determined by quality management which includes planning, implementation and quality control as an effort to carry out continuous improvement in order to improve the ability to carry out three pillars that meet quality standards. This quality management is practically a central part of the Internal Higher Education Quality Assurance System (SPMI) conducted by the Quality Assurance Agency (LPM). The achievement of quality assurance objectives is carried out through SPMI to then obtain accreditation through the External Quality Assurance System (SPME) by BAN-PT.

Entering the era of industrial revolution 4.0, Islamic Studies Study Program UIN Raden Fatah will apply the internet-based learning or Information Technology (ICT) approach. This is important to provide flexibility in choosing the time and place to access teaching materials as well as independent learning, providing opportunities for learners to independently control the success of learning and cost efficiency, providing cost efficiency for administrators, efficiency in providing physical facilities and facilities for learning and cost efficiency for learners is the cost of transportation and accommodation, facilitating and expanding access to education, increasing education equality, improving the quality of learning (the delivery of quality learning and teaching) and increasing the professionalism of teachers, and increasing the effectiveness and efficiency of management, governance and educational administration. The application of ICT-based learning in Islamic Studies study programs in an effort to support the vision of Islamic Studies study programs to be an excellent study program and the vision of UIN Raden Fatah is "Becoming an International Standard University, with Nationalism and Islamic Characteristics.

\section{REFERENCES}

[1] Universitas Islam Negeri Raden Fatah Palembang, "Visi Misi dan Tujuan" [Online] Retrieved from: http://radenfatah.ac.id/2/visi-misi-dantujuan.

[2] M. Sirozi, "Sambutan Rektor Pada Wisuda Sarjana Ke-62 Tanggal 09 Desember 2017" [online] Retrieved from http://radenfatah.ac.id/pimpinan/1/sambutan-rektor-pada-wisudasarjana-ke-62.

[3] S. Margono, Metodologi Penelitian Pendidikan. Jakarta: Rineka Cipta, 1997, pp. 36.

[4] N. Muhajir, Metode Penelitian Kualitatif. Yogyakarta: Rake Sarasin, 1996), Page. 49; and Suharsimi Arikunto, Prosedur Penelitian; Suatu Pendekatan Praktik, Revised edition. Jakarta: PT. Rineka Cipta, 1992, pp. 10.

[5] Sukardi, Metodologi Penelitian Kompetensi dan Praktiknya. Jakarta: PT. Bumi Aksara, 2005, pp. 14.

[6] A.C. Alwasilah, Pokoknya Kualitatif: Dasar-Dasar Merancang dan Melakukan Penelitian Kualitatif. Jakarta: Dunia Pustaka, 2002, pp. 175176 and 186.

[7] J. Vredenbregt, Metode dan Teknik Penelitian Masyarakat. Jakarta: Gramedia, 1980.

[8] S. Abbas, Manajemen Perguruan Tinggi: Beberapa Catatan. Jakarta: Prenadamedia, 2014, pp. 98.

[9] BAN-PT: Standar dan Prosedur Akreditasi Institusi Perguruan Tinggi, Buku II, Standar dan Prosedur. Jakarta: Badan Akreditasi Nasional Perguruan Tinggi, 2011.

[10] L. Setiawati, "Efektivitas Pengembangan Manajemen Pendidikan Tinggi (Studi pada Perguruan Tinggi Negeri di Jawa Barat Menuju World Class University)". Jurnal Penelitian Pendidikan, vol. 13, no. 2, pp. 5, 2012.

[11] L. Huriyah, Endraswari, "Penerapan Toral Quality Management (TQM) Dalam Peningkatan Mutu Layanan Publik UIN Sunan Ampel Surabaya”. In JOIES: Journal of Islamic Education Studies, vol. 1, no. 2, pp. 304, 2016.

[12] C.N. Primiani, "Total Quality Management dan Service Quality dalam Organisasi Pendidikan Tinggi," In Jurnal Cakrawala Pendidikan, Juni 2005, pp. 179-180.

[13] Th. Widia Soerjaningsih, "Peningkatan Mutu Proses Perguruan Tinggi Melalui Sistem Mutu ISO 9000," In Journal The WInners, vol. 5, no. 2 , September 2004, pp. 80.

[14] UIN Radan Fatah, Buku III A Borang Akreditasi Prodi Studi Islam S2 Pascasarjana UIN Palembang Tahun 2018. Palembang: Pascasrajana UIN Raden Fatah, 2018, pp. 11.

[15] S. Abbas, Manajemen Perguruan Tinggi: Beberapa Catatan. pp. 149.

[16] A. Mandagi, "Peningkatan Peringkat Akreditasi Program Studi: Tantangan Terhadap Penjaminan Mutu dan Kualitas Pelayanan di Era Globalisasi," Jurnal Teknik dan Ilmu Komputer, vol. 02, no. 07, JuliSeptember, 2013, pp. 307-308.

[17] Sugiyono, Sutopo, and A. Nuryanto, "Laporan Penelitian Studi Evaluasi Performance Program Studi PGSD Pasca Akreditasi," Jakata: Badan Akreditasi Nasional Perguruan Tinggi Tahun 2012, 2012, pp. 2.

[18] Interview with Muhammad Sirozi, Rektor, UIN Raden Fatah Palembang, at 25 September 2018 in rectorat building UIN Raden Fatah Palembang and interview with Duski Ibrahim, Direktur PPs UIN Raden Ftah Palembang, at 24 September 2018 in Ruang Direktur PPs UIN Raden Fatah Palembang.

[19] Interview with Head of Islamic Studies Study Program, Ahmad Zainuri, tanggal 10 Oktober 2018 in Islamic Studies Study Program room PPs UIN Raden Fatah Palembang. 